\title{
Isolation, Characterization and Antibiotic Resistance Profile Studies of Bacteria from an Excavated Pond in Port Harcourt Metropolis, Nigeria
}

\author{
*ABU, GO; WONDIKOM, AC \\ Department of Microbiology, University of Port Harcourt. PMB 5323. Port Harcourt, Nigeria. \\ *Corresponding Author Email: gideon.abu@uniport.edu.ng; gideonabu1@yahoo.com; divineyoucan@gmail.com
}

\begin{abstract}
The Antibiotic Resistance profile of bacteria isolated from Rumuola pond water in the Port Harcourt metropolis, Rivers State, Nigeria was investigated. Total of 48 bacterial species were isolated on Nutrient Agar and a set of selective diagnostic media. The isolates were identified as Escherichia coli, Staphylococcus sp.; Shigella sp.; Klebsiella sp.; Vibrio sp.; and Salmonella sp. The total culturable heterotrophic bacterial count (TCHB) and faecal coliform count of the water samples ranged from $1.02 \times 10^{6}-1.90 \times 10^{6} \mathrm{cfu} / \mathrm{ml}$ and $3.70 \times 10^{5}-8.15 \times 10^{5} \mathrm{cfu} / \mathrm{ml}$ respectively. The sensitivity of the isolates from the water samples to 12 different antibiotics selected was ascertained on Muller-Hinton agar using the Kirby-Bauer disc diffusion method. The zone diameter obtained was interpreted using the Clinical Laboratory Standard International (CLSI) and British Society for Antimicrobial Chemotherapy (BSAC) zone diameter breakpoints. Isolates were recorded as susceptible (S), intermediate susceptible (I) or resistant (R) based on the guidelines. The level of resistance exhibited by the isolates to specific antibiotics used were; Lincocin $74.8 \%$, Rifampicin $71.4 \%$, Augumentin $71.2 \%$, Chloramphnicol $68.2 \%$, Erythromycin $64.3 \%$, Cotrimoxazole 55.8\%, Streptomycin 50.2\%, Pefloxacin 48.6\%, Gentamycin 43\%, Norfloxacin 42.9\%, Ofloxacin 16.2\%, Ciprofloxacin 13\%. The resistance to Lincocin $(74.8 \%)$ was the highest followed by Rifampicin $(71.4 \%)$. The highest level of bacterial resistance pattern to all tested antibiotics was observed in sites with highest human activities. The result showed multiple antibiotic resistance patterns among the bacterial isolates suggesting a pool of resistance genes among isolates in the pond. Most of the bacterial isolates are potential pathogens. Modern health services for effective disease management for this community would include antibiotic/drug mapping for individuals.
\end{abstract}

\section{DOI: https://dx.doi.org/10.4314/jasem.v22i8.6}

Copyright: Copyright (C) 2018 Abu and Wondikom. This is an open access article distributed under the Creative Commons Attribution License (CCL), which permits unrestricted use, distribution, and reproduction in any medium, provided the original work is properly cited.

Dates: Received: 01July 2017; Revised: 22 July: 2018; Accepted: 17August 2018

Keywords: Antibiotic Resistance, Rumuola Pond, Port Harcourt

In Nigeria, the input of environmental pollutants in aquatic system is a common phenomenon (Abu and Egenonu, 2008). The indiscriminate use of antibiotics in Nigeria is on the increase particularly in animal husbandry where they are used as growth promoters. Research has also shown that there has been a "sigmoid rise in resistance overtime in the presence of a constant rate of antibiotic consumption" at a thresh hold level (Austin et al., 1999). The Rumuola pond is among the important water resources in Port-Harcourt metropolis, Rivers State, Nigeria. The pond receives pollutants from municipal waste water, and surface runoff resulting from soil erosion, domestic and industrial practices in that area. These may lead to wide scale contamination of the pond. Many people within the area are directly dependent on the pond water for their agricultural, recreational and sometimes domestic activities thus exposing the entire community to microbial contamination that could result to water-borne diseases. Dugout or excavated ponds are constructed in areas of flat or gently sloping land not suited for ponds with dams. As the name implies, dug ponds are created by removing soil and allowing water to fill in the dugout area. Most of the water supply comes from ground water seepage or natural springs. Soils are usually made up of materials that allow free movement of water through the pond bottom. Pond water serves as a natural habitat of pathogenic bacterial strains which harbor virulence factors that could play a role in disease process, as well as various multi-drug resistant water-borne pathogens. Similarly increase of faecal pollution in source water is also a problem in developing as well as developed countries (Sinton et al., 1993; Bezuidenhout et al., 2002). This problem is further aggravated where there is lack of sanitation systems, thus posing an increased risk for the outbreak of water-borne diseases (Pretorius, 2000). The World Health Organization (WHO) estimates that 3.4 million people, mostly children die every year from water-related diseases (Wilkes et al., 2009).As ponds are one of the major sources of fish production, the development and spread of resistance to antibiotics by pond bacteria is a major public health threat, it could have serious

*Corresponding Author Email:

gideon.abu@uniport.edu.ng; gideonabu1@yahoo.com; divineyoucan@gmail.com 
medical and economic implications. These resistant pathogens may be transmitted to humans and farm animals causing infections that cannot be treated by conventional antibiotics (Khachatourians, 1998). Resistance of bacteria to antibiotics has been attributed to the misuse and overuse of antibiotics as well as the possession of drug resistant plasmids (Dub Mendel, 2005). According to House of Lords (1998), all antibiotic resistance has a genetic basis. It is part of bacteria defense mechanisms, enhancing its ability to survive in hostile environments (Gershman, 1997). During evolution, bacterial species have become capable of transferring virulence genes not only between members of a particular species but also between different bacteria species creating new pathotypes with new combinations of different virulence genes (Schubert et al., 1998).

Several pathogens have been shown to demonstrate a significant increase in resistance to some specific antibiotics over a short period of time (Coker and Adefeso, 1994; Hoge et al., 1998), either as a result of selective pressure, antibiotics abuse by humans or over use in animals (White et al., 2000). A danger of resistance exists among $5-10 \%$ of infections treated which leads to lack of success or long treatment (Fish et al., 1995; Milatovic and Braveny, 1987). The infections caused by resistant bacteria increase the risk of death and disease transmission as a result of their adaptation towards different Aqua media (Mateos et al., 1993). This has been related to the horizontal transfer of genetic elements like plasmids and class 1 integrones (Jacobs and Chinia, 2006). Antibiotic usage must therefore be carefully regulated and monitored in the environment (Ademola et al., 2009), to assess their impact and subsequent risk to the ecosystem. The aim of this study is to isolate, characterize and identify bacterial species from a dug out (Rumuola) pond in the Port Harcourt Metropolis; the isolates were subjected to antibiotic resistance profile studies to determine the level of antibiotic resistance gene among the isolates from the pond. Rumuola pond receives pollutants, municipal waste water, and surface runoff resulting from soil erosion, domestic and industrial practices in that area.

\section{MATERIALS AND METHODS}

Area of study: The study was conducted at 8 sites within the Rumuola pond in the Port Harcourt Metropolis of Rivers State, Nigeria. Rumuola is located at an elevation of $466 \mathrm{~m}$ above sea level. The pond has coordinates in degrees minutes and seconds (DMS) of $4^{\circ} 49^{\prime} 54^{\prime \prime} \mathrm{N}$ and $7^{\circ} 0^{\prime} 17^{\prime} \mathrm{E}$. This pond receives pollutants, municipal wastewater and natural run off from domestic and industrial practices in that area. Rumuola pond serves as an important fishing ground for people residing in that area.

Sample collection: Water samples were aseptically taken at different sites of the pond using 1 liter sterile screw-capped bottles. The bottles were opened at about $15 \mathrm{~cm}$ depth, allowed to fill, closed under water, and quickly transferred into an ice container. All sites were georeferenced using a hand held global positioning system (GPS) receiver unit (Magellan GPS 315) to generate geographic coordinates (longitudes and latitudes) on the Rumuola pond. The water samples were then transported to the laboratory and analyzed within $8 \mathrm{hr}$ of collection.

Isolation of potential bacterial pathogens: The spread plate method was used for isolation of bacterial pathogens from the water samples using nutrient agar and selective diagnostic media. One milliliter of each water sample was aseptically withdrawn with a sterile pipette, and serially diluted in physiological saline to the fourth dilution using a ten-fold serial dilution. About $0.1 \mathrm{ml}$ aliquot of each dilution was inoculated onto duplicate set of nutrient agar and Eosin methylene blue (EMB) agar, to determine total aerobic heterotrophic bacterial (THB) population and faecal coliforms respectively. The water samples were also enriched on alkaline peptone water $(\mathrm{pH} \mathrm{8.3)}$ and in selenite $\mathrm{F}$ broth and then spread plated on thiosulphate citrate bile sucrose (TCBS) agar and salmonellashigella (S-S) agar respectively for isolation of Vibrio species, Salmonella and Shigella species. Aliquots from diluted water samples were also spread plated on mannitol salt agar (MSA) for the isolation of Staphylococcus species.

All plates were incubated at $35^{\circ} \mathrm{C}$ for 24 hours with the exception of $\mathrm{EMB}$ plates meant for the isolation of faecal coliforms which were incubated at $44.5^{\circ} \mathrm{C}$ for 24 hours.

Purification of isolates: Single colonies of bacteria were randomly selected from different media plates based on their morphology. These bacterial cultures were subsequently isolated in pure forms by subculturing on nutrient agar plates and stored on nutrient agar slants in the refrigerator at $4^{\circ} \mathrm{C}$ until used for microscopic characterization and biochemical analysis.

Characterization and identification of bacterial isolates: The bacterial isolates were characterized and identified based on their motility, microscopic morphology, colonial morphology and biochemical characterization as described in medical laboratory manual for tropical countries (Cheesbrough, 2005) 
and with reference to the Bergey's Manual of Systematic Bacteriology (Krieg and Holt, 1994).

Biochemical tests: Pure cultures of the test organisms as determined by their Gram reaction were used for the various biochemical tests. Unless otherwise stated, the test cultures for the biochemical tests were prepared by inoculating nutrient broth with each isolate from the stock culture. This was incubated for 18-24 hour at $37^{0} \mathrm{C}$.

Test of Indole production: Indole, a nitrogencontaining compound formed when the amino acid tryptophan is hydrolysed by bacteria that have the enzyme Tryptophanase, was tested for by inoculating tubes of peptone water with each of the test organisms. The inoculated tubes were incubated at $35^{\circ} \mathrm{C}$ for 24 hour. After incubation, I ml of Kovac's reagent was added to each tube, shake gently, and allowed to settle. A red band on the surface indicated a positive result.

Methyl Red (MR) Test: This is a qualitative test of acid production by bacteria grown in MR-VP broth. Tubes containing MR-VP broth were inoculated with each of the test cultures and incubated at $37^{\circ} \mathrm{C}$ for $24-48$ hour. After incubation, five drops of $0.4 \%$ (w/v) Methyl red indicator were added to each tube and the tubes observed for any change in colour. A bright red colour was indicative of a positive result; a yellow or orange colour indicated a negative result.

Voges-Proskauer (VP) Reaction: VP-positive bacteria employ the Butanediol fermentation pathway and produce Acetylmethlcarbinol or Acetoin, which reacts with Barritt's reagents $\mathrm{A}$ and $\mathrm{B}$ to produce a red colour. Tubes containing MR-VP broth were inoculated with each of the test culture and incubated at $37^{\circ} \mathrm{C}$ for $48 \mathrm{~h}$. After incubation, $0.4 \mathrm{ml}$ of Barritt's reagent $A$ and $0.6 \mathrm{ml}$ of Barritt's reagent $B$ were added to the tubes. The tubes were shaken vigorously to mix, allowed to stand and observed for the gradual formation of a red colour, indicative of a positive test. Yellow or brown colour indicated a negative test.

Citrate Utilization Test: The Citrate test uses a medium in which Sodium citrate is the only source of carbon and energy. If an organism can use citrate as the sole source of Carbon and energy, it will need to use ammonium salts for Nitrogen. This will result in the release of ammonia, causing a colour change in the medium from green to blue. Tubes of Simon's citrate agar were each inoculated with a test organism and incubated at $35^{\circ} \mathrm{C}$ for 48 hours. A change in the medium from green to royal blue was recorded as a positive test.
Triple Sugar Iron (TS1) agar reaction: TSI agar contains $\mathrm{FeSO}_{4}$ which combines with $\mathrm{H}_{2} \mathrm{~S}$ to produce a black precipitate FeS. It also contains three sugars; Glucose, Lactose, and Sucrose in the ratio 1:10:10. If the organisms ferment lactose and/or sucrose, all the agar in the tube will turn yellow. If only glucose is fermented, the agar will turn yellow from the acid produced. The concentration of glucose is one-tenth that of lactose and sucrose, so it is quickly used up. Ammonia is therefore liberated into the medium by the bacteria at the surface of the slant near air, due to a switch to protein utilization. The ammonia released causes the slant to turn red. Thus, utilization of sucrose and/or lactose leads to the production of acid, causing the slant and butt to turn yellow. Glucose fermentation causes the slant to turn red/pink (alkaline) while the butt is yellow. Tubes containing TSI agar were inoculated with each of the isolates by streaking the top of the slant and stabbing the centre, down to the butt, with each of the inoculums. The tubes were incubated at $35^{\circ} \mathrm{C}$ for 48 hours. The tubes were observed after incubation for the production of $\mathrm{H}_{2} \mathrm{~S}$ gas (winch was indicated by a black colouration of medium), and acid in slant and butt.

Slide Catalase test: Catalase test is aimed at identifying organisms that produce the enzyme catalase, which converts Hydrogen peroxide to water and oxygen bubbles. A drop of 3\% hydrogen peroxide was placed on a dry, clean, grease-free slide, and a colony of the test culture was placed in the drop of hydrogen peroxide and mixed. An immediate release of gas bubble indicated a positive result.

Motility test: The motility test is aimed at determining the presence or absence of flagella as organelles of motion in test organisms. Motility agar test tubes were stabbed at the centre with test isolates and incubated at $37^{\circ} \mathrm{C}$ for 24 hours. Motile organisms grew outwards, horizontally, from the line of stab giving a brush-like appearance while non motile organisms grew only along the stab line.

Antibiotic susceptibility studies:Antibiogram of the selected isolates from water samples in this study was ascertained on Mueller-Hinton agar using the KirbyBauer disc diffusion method (Bauer et al., 1999). A total of 12 antibiotics corresponding to drugs most commonly used in the treatment of human and animal infections caused by gram negative and gram positive bacteria were employed in this study. The antibiotics and their concentration included Augumentin ( $\beta$ lactams) $30 \mu \mathrm{g}$, Streptomycin (Aminoglycosides) 10 $\mu \mathrm{g}$, Ciprofloxacin (Flouroquinolones) $10 \mu \mathrm{g}$, Gentamycin (Aminoglycosides) $10 \mu \mathrm{g}$, Rifampicin (Ansamycin) $20 \mu \mathrm{g}$, Ofloxacin (Quinolones) $10 \mu \mathrm{g}$, 
Norfloxacin (flouroquinolones) $10 \mu \mathrm{g}$, Erythromycin (Macrolides) $30 \mu \mathrm{g}$, Pefloxacin (Quinolones) $10 \mu \mathrm{g}$,

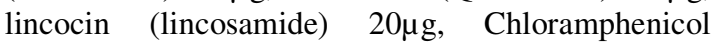
(phenicols) $30 \mu \mathrm{g}$, Cotrimoxazole (sulphonamides) $30 \mu \mathrm{g}$. Overnight cultures of the bacterial isolates were inoculated into peptone water and incubated at $37^{\circ} \mathrm{C}$ for 3-4hours. The density of the bacterial culture required for the assay was adjusted to $0.5 \mathrm{McF}$ arland standards. The Mueller-Hinton agar plates were uniformly inoculated by spotting $0.1 \mathrm{ml}$ of the broth culture of each isolate and streaking over the entire plate, in at least three planes, using a swab stick. The plates were allowed to dry for $10 \mathrm{~min}$; with sterile forceps, antibiotic impregnated paper discs were aseptically placed on the surface of the MuellerHinton agar medium at equidistance to each other and plates were incubated at $37^{\circ} \mathrm{C}$ for 24 hours. A clear zone of inhibited growth around each antibiotic impregnated disc was measured. The degree of susceptibility of the test organism to each antibiotic was determined and interpreted as either sensitive (S), intermediate susceptible (I), or resistant (R) in accordance with the British society for antimicrobial chemotherapy (BSAC), (Andrew, 2007), and Clinical laboratory standard institute.

\section{RESULTSAND DISCUSSION}

Isolation, Characterization and Identification of Bacteria from Rumuola Pond: A Total of 9 Genera of bacteria (48 bacterial species) were isolated from Rumuola pond and identified, they are: Vibrio spp.; Klebsiellaspp; Salmonella spp.; Staphylococcus spp.; Escherichia coli; and Shigellaspp. The Total Culturable Heterotrophic Bacterial (THB) counts and faecal coliform counts of the water samples ranged from $1.02 \times 10^{6}-1.90 \times 10^{6} \mathrm{cfu} / \mathrm{ml}$ and $3.70 \times 10^{5-}$ $8.15 \times 10^{5} \mathrm{cfu} / \mathrm{ml}$ respectively (Table 1 ).

Table1: Total Culturable Heterotrophic Bacterial (TCHB) count and Faecal Coliform Bacterial (FCB) counts of water sample from

\begin{tabular}{lll}
\multicolumn{3}{c}{ Rumuola pond. } \\
Site & $\begin{array}{l}\text { TCHB } \\
(\mathbf{c f u} / \mathbf{m l})\end{array}$ & $\begin{array}{l}\text { FCB } \\
(\mathbf{c f u} / \mathbf{m l})\end{array}$ \\
\hline $\mathrm{Sw}_{1}$ & $1.90 \times 10^{6}$ & $5.90 \times 10^{5}$ \\
$\mathrm{Sw}_{2}$ & $1.61 \times 10^{6}$ & $5.80 \times 10^{5}$ \\
$\mathrm{Sw}_{3}$ & $1.02 \times 10^{6}$ & $5.65 \times 10^{5}$ \\
$\mathrm{Sw}_{4}$ & $1.31 \times 10^{6}$ & $3.70 \times 10^{5}$ \\
$\mathrm{Sw}_{5}$ & $1.59 \times 10^{6}$ & $5.50 \times 10^{5}$ \\
$\mathrm{Sw}_{6}$ & $1.76 \times 10^{6}$ & $6.10 \times 10^{5}$ \\
$\mathrm{Sw}_{7}$ & $1.54 \times 10^{6}$ & $8.15 \times 10^{5}$ \\
$\mathrm{~S} \mathrm{w}_{8}$ & $1.40 \times 10^{6}$ & $5.30 \times 10^{5}$ \\
AV.TVC & $1.52 \times 10^{6}$ & $6.0 \times 10^{5}$ \\
\hline \multicolumn{3}{c}{ value of the duplicate counts. }
\end{tabular}

Antibiotic Susceptibility Profile of Bacterial Groups in Rumuola Pond Water Samples: Results obtained in the antibiotic susceptibility test of the isolates are presented in Tables 2 and 3 and Fig1. The results revealed marked differences among bacterial isolates in their susceptibility and resistance patterns to antibiotics. The highest rate of resistance $(74.8 \%)$ was recorded against lincocin by all isolated species followed by Rifampicin (71.4\%).Ciprofloxacin (13\%) recorded the least resistance. All the isolates with the exception of Escherichia coli. ( $\left.\mathrm{sw}_{2} \mathrm{~b}\right), \quad$ Vibrio $\mathrm{sp} .\left(\mathrm{sw}_{2} \mathrm{f}\right)$, Klebsiella $\mathrm{sp} .\left(\mathrm{sw}_{3} \mathrm{c}\right)$ and Vibrio $\mathrm{sp} .\left(\mathrm{sw}_{8} \mathrm{~g}\right)$ exhibited resistance to at least one of the following drugs. Gentamycin, Ciprofloxacin, and Norfloxacin.

All the isolates showed susceptibility to ciprofloxacin, except few isolates of Klebsiella sp., Shigella sp., Salmonella sp., and Staphylococcus sp. All isolates showed $100 \%$ resistance to Augumentin with the exception of few strains of Escherichia coli, Shigellaspand Klebsiellasp.In $\mathrm{sw}_{1}, \quad \mathrm{sw}_{3}$ and $\mathrm{sw}_{6}$ Salmonella sp. and Escherichiacoliwere not isolated. Staphylococcus strains in $\mathrm{sw}_{1}$ were only susceptible to two antibiotics namely ciprofloxacin and ofloxacin. The isolates in $\mathrm{sw}_{2}$ showed $100 \%$ resistance to Rifampicin, Erythromycin and Augumentin while varying in other antibiotics. All the Salmonella isolates showed resistance to chloramphenicol. The proportion of the antibiotic resistant bacteria was lowest at $\mathrm{sw}_{8}$ for most of the antibiotics. Bacterial isolates from $\mathrm{Sw}_{2}$ showed the highest level of resistance. They exhibited 100\% resistance to Lincocin, Rifampicin, Erythromycin and Augumentin. The level of resistance exhibited by the isolates to specific antibiotics used were; Lincocin $74.8 \%$, Rifampicin 71.4\%, Augumentin 71.2\%, Chloramphnicol 68.2\%, Erythromycin $64.3 \%$, Cotrimoxazole $55.8 \%$, Streptomycin 50.2\%, Pefloxacin 48.6\%, Gentamycin 43\%, Norfloxacin $42.9 \%$, Ofloxacin $16.2 \%$ and Ciprofloxacin $13 \%$.The current level of faecal coliforms load observed in this study especially in $\mathrm{sw}_{7}$ suggests that Rumuola pond is unfit for domestic purposes including human consumption. This may be due to pollution in the area caused by human activities (such as human waste disposal, defecation, fishing and swimming). Climate change and other heightened ecological disturbances such as flooding are all possible sources of contamination (Nevondo and Cloete, 1999; Obi et al., 2002; Mbah et al., 2016). These multiple sources of contamination are compounded by limited environmental awareness, which is prominent in rural areas (Garcia et al., 1987, Dick et al., 2015) but also in urban areas such as the Rumuola Pond area in Port Harcourt. The results of the antibiotic test conducted on the isolates shows the presence of resistance to naturally, chemically modified and synthetic antibiotics (Table 2). The highest level of bacterial resistance pattern to all tested antibiotics was observed in $\mathrm{Sw}_{2}$. The least resistance pattern to the tested 
antibiotics was observed in $\mathrm{Sw}_{8}$. The sources of bacteria are probably diverse, with soil microorganisms contributing greatly to the pool of resistance genes (Oganet al., 1993).

Table2. Antibiotic sensitivity profile of bacteria isolated from Rumuola Pond in Port Harcourt

\begin{tabular}{|c|c|c|c|c|c|c|c|c|c|c|c|c|c|}
\hline \multirow[b]{2}{*}{ SITE } & \multirow[b]{2}{*}{ ISOLATES } & \multicolumn{12}{|c|}{ ANTIBIOTICS SENSITIVITY PROFILE } \\
\hline & & $\mathbf{C N}$ & $\mathbf{S}$ & $\mathbf{L C}$ & CPX & $\mathbf{R X}$ & $\mathbf{E}$ & NOR & CH & OFX & PEF & $\mathbf{A U}$ & SXT \\
\hline \multirow[t]{6}{*}{ SW1 } & Klebsiellasp. & $\mathbf{S}$ & $\mathbf{S}$ & $\mathbf{R}$ & $\mathbf{S}$ & $\mathbf{R}$ & $\mathbf{I}$ & $\mathbf{R}$ & $\mathbf{R}$ & $\mathbf{R}$ & $\mathbf{R}$ & $\mathbf{R}$ & $\mathbf{I}$ \\
\hline & Vibrio sp. & $\mathbf{S}$ & $\mathbf{S}$ & $\mathbf{I}$ & $\mathbf{S}$ & $\mathbf{I}$ & $\mathbf{R}$ & $\mathbf{S}$ & $\mathbf{S}$ & $\mathbf{S}$ & $\mathbf{R}$ & $\mathbf{R}$ & $\mathbf{R}$ \\
\hline & Klebsiellasp. & $\mathbf{I}$ & $\mathbf{R}$ & $\mathbf{R}$ & $\mathbf{S}$ & $\mathbf{R}$ & $\mathbf{R}$ & $\mathbf{R}$ & $\mathbf{R}$ & $\mathbf{S}$ & $\mathbf{R}$ & $\mathbf{R}$ & $\mathbf{R}$ \\
\hline & Staphylococcus sp. & $\mathbf{R}$ & $\mathbf{R}$ & $\mathbf{R}$ & $\mathbf{R}$ & $\mathbf{R}$ & $\mathbf{R}$ & $\mathbf{R}$ & $\mathbf{R}$ & $\mathbf{S}$ & $\mathbf{R}$ & $\mathbf{R}$ & $\mathbf{R}$ \\
\hline & Staphylococcus sp. & $\mathbf{I}$ & $\mathbf{R}$ & $\mathbf{R}$ & $\mathbf{S}$ & $\mathbf{R}$ & $\mathbf{R}$ & I & $\mathbf{I}$ & $\mathbf{S}$ & $\mathbf{S}$ & $\mathbf{R}$ & $\mathbf{R}$ \\
\hline & Staphylococcus sp. & $\mathbf{R}$ & $\mathbf{R}$ & $\mathbf{S}$ & $\mathbf{S}$ & $\mathbf{R}$ & $\mathbf{R}$ & I & $\mathbf{R}$ & $\mathbf{S}$ & $\mathbf{S}$ & $\mathbf{R}$ & $\mathbf{R}$ \\
\hline \multirow[t]{6}{*}{ SW2 } & Staphylococcus sp. & $\mathbf{R}$ & $\mathbf{R}$ & $\mathbf{S}$ & I & $\mathbf{R}$ & $\mathbf{R}$ & $\mathbf{R}$ & $\mathbf{R}$ & I & $\mathbf{S}$ & $\mathbf{R}$ & $\mathbf{R}$ \\
\hline & Escherichia coli & $\mathbf{S}$ & $\mathbf{R}$ & $\mathbf{S}$ & $\mathbf{S}$ & $\mathbf{R}$ & $\mathbf{R}$ & $\mathbf{S}$ & $\mathbf{I}$ & $\mathbf{S}$ & $\mathbf{S}$ & $\mathbf{R}$ & $\mathbf{S}$ \\
\hline & Klebsiellasp. & $\mathbf{S}$ & $\mathbf{R}$ & $\mathbf{R}$ & $\mathbf{R}$ & $\mathbf{R}$ & $\mathbf{R}$ & $\mathbf{R}$ & $\mathbf{R}$ & $\mathbf{S}$ & $\mathbf{S}$ & $\mathbf{R}$ & $\mathbf{R}$ \\
\hline & Klebsiellasp. & $\mathbf{R}$ & $\mathbf{R}$ & $\mathbf{R}$ & $\mathbf{S}$ & $\mathbf{R}$ & $\mathbf{R}$ & I & $\mathbf{R}$ & $\mathbf{S}$ & $\mathbf{R}$ & $\mathbf{R}$ & $\mathbf{R}$ \\
\hline & Salmonella sp. & $\mathbf{R}$ & $\mathbf{S}$ & $\mathbf{R}$ & $\mathbf{S}$ & $\mathbf{R}$ & $\mathbf{R}$ & I & $\mathbf{R}$ & $\mathbf{S}$ & $\mathbf{S}$ & $\mathbf{R}$ & $\mathbf{S}$ \\
\hline & Vibrio sp. & I & $\mathbf{R}$ & $\mathbf{R}$ & $\mathbf{S}$ & $\mathbf{R}$ & $\mathbf{R}$ & $\mathbf{S}$ & $\mathbf{R}$ & $\mathbf{S}$ & I & $\mathbf{R}$ & $\mathbf{R}$ \\
\hline \multirow[t]{5}{*}{ SW3 } & Vibrio sp. & $\mathbf{R}$ & $\mathbf{S}$ & $\mathbf{R}$ & I & $\mathbf{R}$ & $\mathbf{R}$ & $\mathbf{S}$ & $\mathbf{R}$ & $\mathbf{S}$ & $\mathbf{S}$ & $\mathbf{R}$ & $\mathbf{R}$ \\
\hline & Shigellasp. & $\mathbf{R}$ & $\mathbf{S}$ & $\mathbf{R}$ & $\mathbf{R}$ & $\mathbf{R}$ & $\mathbf{R}$ & $\mathbf{R}$ & $\mathbf{R}$ & $\mathbf{S}$ & $\mathbf{R}$ & $\mathbf{R}$ & $\mathbf{R}$ \\
\hline & Klebsiellasp. & $\mathbf{S}$ & $\mathbf{S}$ & I & $\mathbf{S}$ & $\mathbf{R}$ & $\mathbf{S}$ & $\mathbf{S}$ & $\mathbf{S}$ & $\mathbf{S}$ & $\mathbf{S}$ & $\mathbf{S}$ & $\mathbf{S}$ \\
\hline & Vibrio sp. & $\mathbf{S}$ & $\mathbf{R}$ & $\mathbf{R}$ & I & $\mathbf{R}$ & $\mathbf{R}$ & I & $\mathbf{S}$ & $\mathbf{S}$ & $\mathbf{S}$ & $\mathbf{R}$ & $\mathbf{R}$ \\
\hline & Shigellasp. & I & $\mathbf{S}$ & $\mathbf{R}$ & $\mathbf{S}$ & I & $\mathbf{R}$ & $\mathbf{S}$ & $\mathbf{R}$ & $\mathbf{S}$ & $\mathbf{S}$ & $\mathbf{R}$ & $\mathbf{R}$ \\
\hline \multirow[t]{5}{*}{ SW4 } & Salmonella sp. & $\mathbf{R}$ & $\mathbf{S}$ & I & $\mathbf{S}$ & $\mathbf{R}$ & $\mathbf{R}$ & $\mathbf{S}$ & $\mathbf{R}$ & I & $\mathbf{S}$ & $\mathbf{I}$ & $\mathbf{S}$ \\
\hline & Staphylococcus sp. & $\mathbf{R}$ & $\mathbf{R}$ & $\mathbf{R}$ & $\mathbf{S}$ & $\mathbf{R}$ & $\mathbf{R}$ & $\mathbf{R}$ & $\mathbf{R}$ & $\mathbf{S}$ & $\mathbf{S}$ & $\mathbf{R}$ & $\mathbf{R}$ \\
\hline & Klebsiellasp. & I & $\mathbf{S}$ & $\mathbf{I}$ & $\mathbf{R}$ & $\mathbf{S}$ & $\mathbf{S}$ & $\mathbf{S}$ & $\mathbf{S}$ & $\mathbf{S}$ & $\mathbf{S}$ & $\mathbf{S}$ & $\mathbf{S}$ \\
\hline & Vibrio sp. & I & $\mathbf{S}$ & $\mathbf{R}$ & $\mathbf{S}$ & I & $\mathbf{R}$ & $\mathbf{S}$ & $\mathbf{S}$ & $\mathbf{R}$ & $\mathbf{S}$ & $\mathbf{R}$ & $\mathbf{S}$ \\
\hline & Klebsiellasp. & $\mathbf{S}$ & $\mathbf{S}$ & $\mathbf{R}$ & $\mathbf{S}$ & $\mathbf{R}$ & $\mathbf{R}$ & $\mathbf{R}$ & $\mathbf{R}$ & $\mathbf{S}$ & $\mathbf{R}$ & $\mathbf{R}$ & $\mathbf{S}$ \\
\hline \multirow[t]{6}{*}{ SW5 } & Escherichia coli & $\mathbf{S}$ & $\mathbf{R}$ & $\mathbf{R}$ & $\mathbf{I}$ & $\mathbf{R}$ & $\mathbf{S}$ & $\mathbf{S}$ & $\mathbf{I}$ & $\mathbf{S}$ & $\mathbf{S}$ & $\mathbf{R}$ & $\mathbf{S}$ \\
\hline & Salmonella sp. & $\mathbf{R}$ & $\mathbf{R}$ & $\mathbf{R}$ & $\mathbf{R}$ & $\mathbf{R}$ & $\mathbf{R}$ & $\mathbf{R}$ & $\mathbf{R}$ & $\mathbf{R}$ & $\mathbf{R}$ & $\mathbf{R}$ & $\mathbf{R}$ \\
\hline & Escherichia coli & $\mathbf{R}$ & $\mathbf{R}$ & $\mathbf{R}$ & $\mathbf{S}$ & $\mathbf{R}$ & $\mathbf{R}$ & $\mathbf{R}$ & $\mathbf{S}$ & $\mathbf{S}$ & $\mathbf{R}$ & $\mathbf{R}$ & $\mathbf{R}$ \\
\hline & Salmonella sp. & $\mathbf{R}$ & $\mathbf{S}$ & $\mathbf{R}$ & $\mathbf{S}$ & $\mathbf{R}$ & $\mathbf{R}$ & $\mathbf{R}$ & $\mathbf{R}$ & I & $\mathbf{R}$ & $\mathbf{R}$ & $\mathbf{R}$ \\
\hline & Shigellasp. & $\mathbf{S}$ & $\mathbf{R}$ & $\mathbf{I}$ & $\mathbf{S}$ & $\mathbf{R}$ & $\mathbf{S}$ & $\mathbf{R}$ & $\mathbf{R}$ & $\mathbf{S}$ & $\mathbf{R}$ & $\mathbf{R}$ & $\mathbf{R}$ \\
\hline & Salmonella sp & I & $\mathbf{S}$ & $\mathbf{R}$ & $\mathbf{S}$ & $\mathbf{S}$ & $\mathbf{R}$ & $\mathbf{S}$ & $\mathbf{R}$ & $\mathbf{S}$ & $\mathbf{R}$ & I & I \\
\hline \multirow[t]{6}{*}{ SW6 } & Klebsiellasp. & I & I & $\mathbf{R}$ & $\mathbf{S}$ & $\mathbf{R}$ & $\mathbf{R}$ & $\mathbf{S}$ & $\mathbf{R}$ & $\mathbf{S}$ & $\mathbf{S}$ & $\mathbf{R}$ & $\mathbf{S}$ \\
\hline & Klebsiellasp. & $\mathbf{S}$ & $\mathbf{R}$ & $\mathbf{R}$ & $\mathbf{S}$ & $\mathbf{R}$ & $\mathbf{R}$ & $\mathbf{R}$ & $\mathbf{R}$ & $\mathbf{S}$ & $\mathbf{R}$ & $\mathbf{R}$ & $\mathbf{S}$ \\
\hline & Klebsiellasp. & $\mathbf{S}$ & $\mathbf{S}$ & $\mathbf{R}$ & $\mathbf{S}$ & $\mathbf{R}$ & $\mathbf{R}$ & $\mathbf{R}$ & $\mathbf{R}$ & $\mathbf{S}$ & $\mathbf{R}$ & $\mathbf{R}$ & $\mathbf{R}$ \\
\hline & Shigellasp. & I & $\mathbf{R}$ & $\mathbf{R}$ & $\mathbf{S}$ & $\mathbf{R}$ & $\mathbf{S}$ & $\mathbf{I}$ & $\mathbf{R}$ & $\mathbf{S}$ & $\mathbf{S}$ & $\mathbf{S}$ & $\mathbf{R}$ \\
\hline & Klebsiellasp. & $\mathbf{R}$ & $\mathbf{I}$ & $\mathbf{R}$ & $\mathbf{S}$ & $\mathbf{R}$ & $\mathbf{R}$ & $\mathbf{R}$ & $\mathbf{S}$ & $\mathbf{R}$ & $\mathbf{S}$ & $\mathbf{S}$ & $\mathbf{S}$ \\
\hline & Staphylococcus sp. & $\mathbf{R}$ & $\mathbf{R}$ & I & $\mathbf{S}$ & $\mathbf{I}$ & $\mathbf{R}$ & $\mathbf{R}$ & $\mathbf{R}$ & $\mathbf{S}$ & $\mathbf{S}$ & $\mathbf{R}$ & $\mathbf{R}$ \\
\hline \multirow[t]{7}{*}{ SW7 } & Staphylococcus sp. & $\mathbf{R}$ & $\mathbf{R}$ & $\mathbf{R}$ & $\mathbf{R}$ & $\mathbf{R}$ & $\mathbf{R}$ & $\mathbf{S}$ & $\mathbf{R}$ & $\mathbf{R}$ & $\mathbf{R}$ & $\mathbf{R}$ & $\mathbf{R}$ \\
\hline & Shigellasp. & $\mathbf{S}$ & $\mathbf{R}$ & $\mathbf{R}$ & $\mathbf{I}$ & $\mathbf{R}$ & $\mathbf{R}$ & $\mathbf{R}$ & $\mathbf{R}$ & $\mathbf{S}$ & $\mathbf{S}$ & $\mathbf{S}$ & $\mathbf{S}$ \\
\hline & Escherichia coli & $\mathbf{R}$ & $\mathbf{S}$ & $\mathbf{R}$ & $\mathbf{S}$ & $\mathbf{R}$ & $\mathbf{S}$ & $\mathbf{S}$ & I & $\mathbf{S}$ & $\mathbf{S}$ & $\mathbf{R}$ & $\mathbf{S}$ \\
\hline & Salmonella sp. & $\mathbf{S}$ & $\mathbf{S}$ & $\mathbf{I}$ & $\mathbf{S}$ & $\mathbf{R}$ & $\mathbf{I}$ & $\mathbf{R}$ & $\mathbf{R}$ & $\mathbf{R}$ & I & $\mathbf{R}$ & $\mathbf{R}$ \\
\hline & Shigellasp. & $\mathbf{S}$ & $\mathbf{R}$ & $\mathbf{R}$ & $\mathbf{S}$ & $\mathbf{R}$ & $\mathbf{R}$ & $\mathbf{R}$ & $\mathbf{R}$ & $\mathbf{I}$ & I & $\mathbf{S}$ & $\mathbf{S}$ \\
\hline & Staphylococcus sp. & I & $\mathbf{S}$ & $\mathbf{R}$ & $\mathbf{S}$ & $\mathbf{R}$ & $\mathbf{S}$ & I & $\mathbf{S}$ & $\mathbf{S}$ & $\mathbf{S}$ & $\mathbf{R}$ & $\mathbf{R}$ \\
\hline & Staphylococcus sp. & $\mathbf{R}$ & $\mathbf{R}$ & $\mathbf{S}$ & $\mathbf{S}$ & I & $\mathbf{S}$ & $\mathbf{R}$ & $\mathbf{R}$ & $\mathbf{S}$ & $\mathbf{S}$ & $\mathbf{S}$ & $\mathbf{R}$ \\
\hline \multirow[t]{7}{*}{ SW8 } & Escherichia coli & $\mathbf{R}$ & I & $\mathbf{S}$ & $\mathbf{R}$ & I & $\mathbf{S}$ & $\mathbf{S}$ & $\mathbf{S}$ & $\mathbf{S}$ & I & I & $\mathbf{S}$ \\
\hline & Klebsiellasp. & $\mathbf{S}$ & $\mathbf{S}$ & $\mathbf{S}$ & $\mathbf{I}$ & $\mathbf{R}$ & I & $\mathbf{R}$ & $\mathbf{R}$ & $\mathbf{S}$ & $\mathbf{R}$ & $\mathbf{R}$ & $\mathbf{R}$ \\
\hline & Shigellasp. & I & $\mathbf{R}$ & $\mathbf{S}$ & $\mathbf{R}$ & $\mathbf{S}$ & I & $\mathbf{R}$ & $\mathbf{R}$ & $\mathbf{S}$ & $\mathbf{R}$ & $\mathbf{R}$ & $\mathbf{S}$ \\
\hline & Staphylococcus sp. & $\mathbf{R}$ & $\mathbf{R}$ & $\mathbf{S}$ & $\mathbf{R}$ & $\mathbf{S}$ & $\mathbf{R}$ & $\mathbf{R}$ & $\mathbf{R}$ & $\mathbf{R}$ & $\mathbf{R}$ & $\mathbf{R}$ & $\mathbf{R}$ \\
\hline & Klebsiellasp & $\mathbf{S}$ & I & $\mathbf{S}$ & $\mathbf{S}$ & $\mathbf{R}$ & $\mathbf{R}$ & $\mathbf{R}$ & $\mathbf{R}$ & $\mathbf{I}$ & $\mathbf{R}$ & $\mathbf{R}$ & $\mathbf{S}$ \\
\hline & Escherichia coli & I & $\mathbf{R}$ & $\mathbf{S}$ & $\mathbf{R}$ & $\mathbf{S}$ & $\mathbf{S}$ & $\mathbf{S}$ & $\mathbf{S}$ & $\mathbf{S}$ & $\mathbf{S}$ & $\mathbf{S}$ & $\mathbf{S}$ \\
\hline & Vibrio sp. & $\mathbf{S}$ & $\mathbf{S}$ & I & $\mathbf{S}$ & $\mathbf{R}$ & $\mathbf{S}$ & I & I & I & $\mathbf{R}$ & $\mathbf{R}$ & $\mathbf{R}$ \\
\hline
\end{tabular}

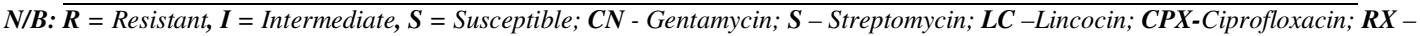
Rifampicin; $\boldsymbol{E}$-Erythromycin; NOR - Norfloxacin; CH-Chloramphenicol; OFX-Ofloxacin; PEF - Pefloxacin; $\boldsymbol{A} \boldsymbol{U}$-Augumentin; $\boldsymbol{S X T}$ Cotrimoxazole. 


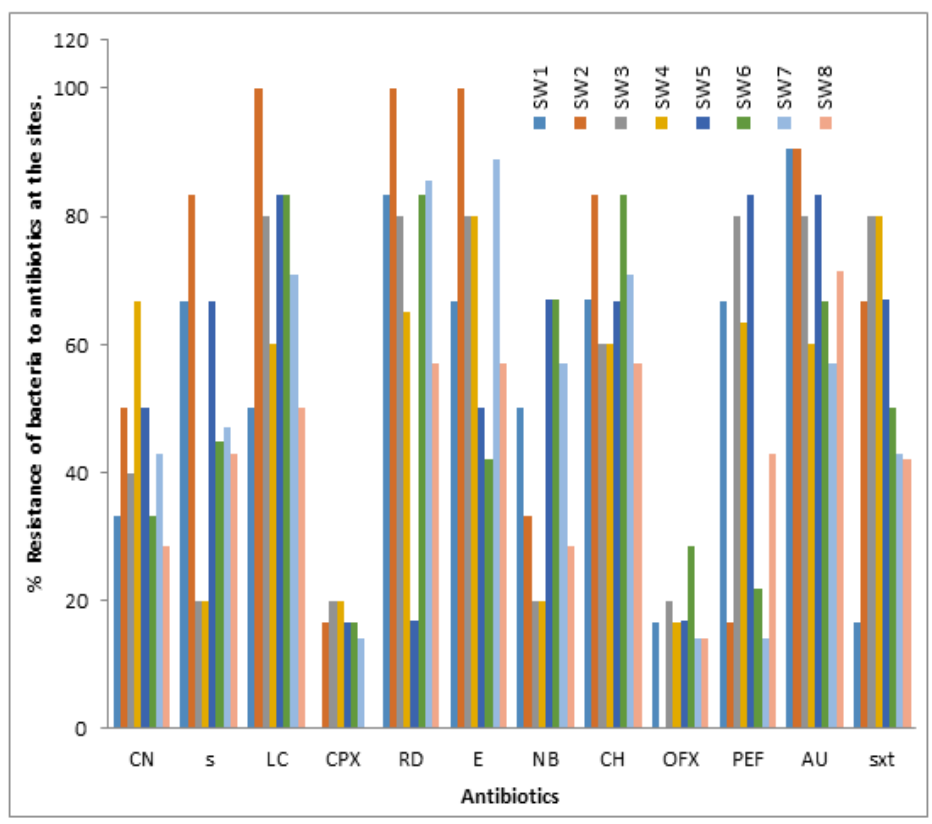

Fig 1: Statistical (Percentage) distribution of resistance to antibiotics among bacteria isolated from the Rumuola pond water at different sites

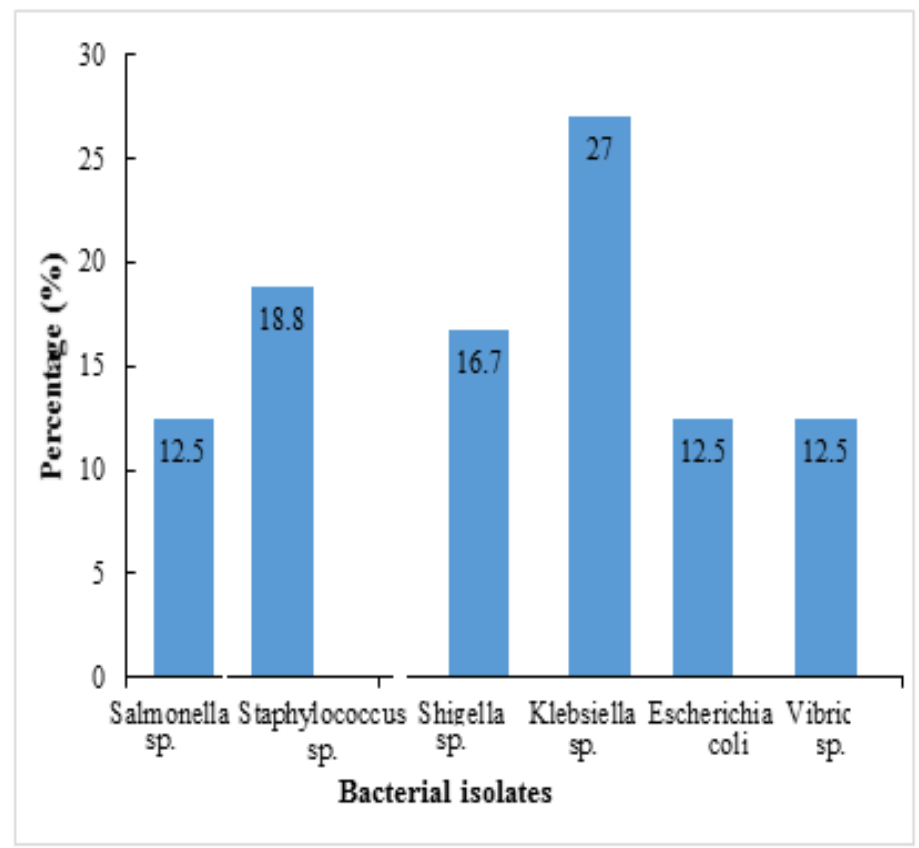

Fig 2: Statistical (Percentage frequency) distribution of potential pathogens among bacteria isolated from Rumuolapond in Port Harcourt.
It should be noted that susceptibility of bacteria to antibiotics is not static and resistance may be due to antibiotic abuse, antibiotic over use or may be chromosomally or plasmid mediated (Obi et al., 1998; Dick et al., 2015). Susceptibility of bacteria to antibiotics could also be altered by the impact of environmental and human activities on such isolates which possibly results in the development and selection of antibiotic resistant strains (Abu and Egenonu, 2008; Dick et al., 2015).This is a health risk as infections caused by these resistant strains are more difficult to treat.

The multi-drug resistance in this study may be attributed to the presence of resistance determinants on plasmids with similar selective markers, it could also be as a result of independent, simultaneous development of resistance to different agents which suggest that bacteria have the unique characteristics of being able to transfer resistance genes from one bacterium to another of different population, occupying different habitats, such as man, animals and the environment. As strains susceptible to all drugs become less common the proportion of isolates resistant to multiple antibiotics increases (Olowe et al., 2008).

Most isolates were sensitive to Ciprofloxacin and Ofloxacin. These drugs therefore may be of value in the treatment of enteric infections requiring empiric antibiotic therapy. It is noteworthy that these antibiotics are not top of the line drugs, so efforts could be stepped up to control further drug resistance in the Rumuola community.
The result obtained in this study showed that all the salmonella isolates had resistance to chloramphenicol. Staphylococcus sp., showed resistance to all the classes of antibiotics to which tested. The presence of Escherichia coli at $\mathrm{Sw}_{2}, \mathrm{Sw}_{5}, \mathrm{Sw}_{7}$ and $\mathrm{Sw}_{8}$ confirms the presence of waste disposal and faecal materials.
The level of resistance among isolates to the $\beta$-lactams suggests that the $\beta$-lactamase genes could be widely present in the gene pool of the bacteria found within the sample sites. Self-medication is a common practice in the study area and is likely to continue, probably, due to poor access to medical services. The use of 
antibiotics in agriculture can select for resistance in farm animals, the resistant organisms and the antibiotics themselves may find their way into surface waters through surface run off and soil erosion. This can confer pressure for the selection of resistance among native organisms. The high incidence of multiple antibiotics resistance among bacterial isolates obtained in this study is indicative of an environmental selective pressure.

Conclusion: Antibiotic resistance as obtained in this study has public health implications, considering the fact that multi-drug resistance was extremely common. Some of the resistant isolates are opportunistic pathogens and infection caused by these organisms may be difficult to treat, which can spread in populations causing out breaks. Health services could include caution on the indiscriminate and inappropriate use of antibiotics, and related compounds on animals and humans. Although Ciprofloxacin and Ofloxacin were effective against the isolates in this study, periodic monitoring using antibiograms is necessary to detect any changes in resistance patterns over time. As concerns about environmental contamination by humans, industrial and agricultural waste is on the increase, it is of importance to develop reliable screening methods that can be used to identify probable contamination sources. Modern health services for effective disease management for this community would include antibiotic/drug mapping for individuals.

\section{REFERENCES}

Abu, GO; Egenonu, C (2008). The current pollution status of the new Calabar River in the Niger Delta region of Southern Nigeria: A survey of antibiogram profiles of its bacterial isolates. African Journal of Environmental Science and Technology 2 (6): 134-141.

Ademola, OO; Kovashnee, N; Balakrishna, P (2009). Antibiotic resistance profiles of Escherichia coli isolates from river sources in Durban, South Africa. World J Microbiol. Biotechnol. 25:17431749.

Andrews, JM (2007). BSAC standardized disc susceptibility testing method (Version 6). Journal of Antimicrobial Chemotherapy.

Austin, DJ; Kristinsson, KG; Anderson, RM (1999). The difference between the volume of antimicrobial consumption in human communities and the frequency of resistance. Journal of National Academy of Science. USA. 96: 1152-1156.
Bauer, AW; Kirby, WMM; Strerris, JC; Turk, M (1999). Antibiotic susceptibility testing by a standard single disk method. American Journal of Clinical Pathology.45: 493-496.

Bezuidenhout, CC; Mthembu, C; Puckree, T; Lin, J (2002). Microbiological evaluation of the Mhlathuze River, KwaZulu-Natal (RSA). Water SA. 28(3): 281-286.

Cheesbrough, M (2002). District laboratory practice in tropical countries, 2 microbiology. Cambridge university press, 132-143.

Coker, AO; Adefeso, AO (1994). The changing patterns of Campylobacter jejuni/coli in Lagos, Nigeria after ten years. East African Medical Journal. 71:437-440.

Dick, Asitona A; Abu, GO; Ibe, SN (2015). Antibiotic sensitivity and plasmid profiles of bacteria isolated from water sources in Oproama community in the Niger Delta. Biokemistri. 27 (1) 14-21. Biokemistri An International Journal of the Nigerian Society for Experimental Biology.

Dub Mendal, M (2005). Experiments on exploration of environmental bacteria degrading a pesticide used in agriculture. Thesis, University of Jadavpur.

Fish, DNS; Piscitelli, ML; Danziger, H (1995). Development of resistance during antimicrobial therapy: a review of antibiotic classes and patient characteristics in 173 studies. Pharmacotherapy, 15: 279-91.

Garcia. V; Ruiz, B; Cueto, EA; Bolanos Carmona, MJ (1987). A comparative study of strains of Salmonella isolated from irrigation Water, vegetables and Human infections. Epidemiol. Infect. 98: 271-276.

Gershman, K (1997). Antibiotic resistance and judicious antibiotic use of[ Electronic Version]. The Medical Report. 2(11). Retrieved, 2013. From http://medicalreporter.health.org/tmr027/antibio tic0297.html

Hoge, CW; Gambel, JM; Srijan A; Pitarangsic C;Echevervia P (1998). Trends in antibiotic resistance among diarrhoeal pathogens isolated in Thailand over 15 years. Clinical Infectious Disease. 26:341-345. 
House of Lords Select Committee on Science and Technology. (1998). $7^{\text {th }}$ Report. The Stationery office. London, Uk.

Jacobs, L; Hadizah, Y; Chenia, G (2006). Characterization of integrons and tetracycline resistance determinants inAeromonas spp. Isolated from South African aquaculture systems. Inter. J. Food Microbial. 13:1717-3998.

Khachathatourians, GG (1998). Agricultural use of antibiotics and the evolution and transfer of antibiotic resistant-bacteria. J. Antimicrobial Chemotherapy. 159: 1129-1136.

Krieg, NR; Holt, JG (1994). Bergey's Manual of Systematic Bacteriology. William and Wilkins, Baltimore Ltd.

Mateos, D. et al, (1993). Influence of growth temperature on the production of extracellular virulence factors and pathologenicity of environmental and human strains of Aeromonashydrophila. J. Appl. Bacteriology, 74: 111-118.

Mbah, EI; Abu, GO; Ibe, SN (2016). MetagenomesBased Investigation of the Impact of Natural Run-offs and Anthropogenesis on a Freshwater Ecosystem at Points of Use in Niger Delta, Nigeria. Intl. J. Innov. Res. Dev. (IJIRD)

Milatovic, D; Braveny, I (1987). Development of resistance during antibiotic therapy. European $J$. Clinical Microbiology. 6:234-44.

Nevondo, TS; Cloete TE (1999) Bacterial and chemical qualities of water supply in Dertig Village Settement. Water SA. 25:215-220.

Obi, CL; Coker AO; Epoke, J;Ndip RN (1998). Distributional pattern of bacterial diarrhoeagenic agents and antibiograms of isolates from diarrhoeic and non-diarrhoeic patients in urban and rural areas of Nigeria. Cent Afr. J Med 44:223-229.
Obi, CL; Potgieter, N; Bessong, PO; Matsaung, G (2002). Assessment of the microbial quality of river water sources in rural communities in South Africa. Water SA. 28:287-292.

Ogan, MT; Nwiika, DE (1993). Studies on the ecology of aquatic bacteria of the lower Niger Delta: multiple antibiotic resistances among the standard plate count organisms. J. Appl. Bacteriol. 74: 595-602.

Olowe, OA; Okanlawon, BM; Olowe, RA; Olayemi, AB (2008).Antimicrobial resistance pattern ofEscherichia coli from human clinical samples in Osogbo, south western Nigeria. Afr. J. Microbiology Res. 2 008-011.

Pretorious, L (2000). An investigation into the effect of various levels of sanitation on surface water quality in a typical developing community. $S A$ Water Bulletin. 26(23):10-12.

Schubert, S; Rakin, A; Karch, H; Carniel, E; Heesemann, J (1998). Prevalence of the 'highpathogenicity island' of Yersinia species among Escherichia coli strains that are pathogenic to humans. J Infect Immun. 66:480-485.

Sinton, LW;Donnison, AM; Hastie, CM (1993). Faecal streptococci as faecal pollution indicators: a review. II. Sanitary significance, survival, and use. N. Z. J. Mar. Freshwater Res. 27: 117-137.

White, DG; Hudson, C; Maurer, JJ; Ayers, S; Zhao, S; Lee, MD; Bolton, L; Foley, T; Sherwood, J (2000). Characterization of chloramphenicol and florfenicol resistance in Escherichia coli associated with bovine diarrhoea. Journal of Clinical Microbiology. 38:4593-4598.

Wilkes, G; Edge, T; Gannon, V; Jokinen. C; Lyautey, E; Medeiros, D; Neumann, N; Ruecker, N Topp, E;Lapen, DR (2009). Seasonal relationships among indicator bacteria, pathogenic bacteria, Cryptosporidium oocysts, Giardia cysts, and hydrological indices for surface waters within an agricultural landscape. Water Res. 43:2209-2223. 